\title{
Ortaokul Öğrencilerinin Teknolojiye Yönelik Tutumlarının Bazı Değişkenler Açısından İncelenmesi*
}

\author{
Sibel GÜRBÜZOĞLU YALMANCI**, Solmaz AYDIN***
}

\section{Öz}

$\mathrm{Bu}$ çalışmanın amacı ortaokul öğrencilerinin teknolojiye yönelik tutumlarının bazı değişkenler açısından incelenmesidir. Çalışmada, genel tarama modeli kullanılmıştır. Araştırmanın örneklemini Kars il merkezindeki ve merkeze bağlı köylerdeki altı orta okulda öğrenim gören ve random olarak seçilen 6., 7. ve 8 . sınıftaki toplam 400 ortaokul öğrencisi oluşturmaktadır. Çalışmada teknolojiye yönelik tutum ölçeğinin Türkçe versiyonu (ÖTYT-TR) kullanılmıştır. Öğrencilerin teknolojiye yönelik tutumlarında cinsiyet ve yerleşim yeri değişkenlerinin etkisini belirlemek için bağımsız gruplar $\mathrm{t}$ testi kullanılmıştır. Sınıf düzeyi değişkeninin etkisini belirlemek için de Tek Yönlü Varyans Analizi- Post Hoc Tukey HSD Testi kullanılarak veri analizi yapılmıştır. Sonuç olarak yerleşim yerine göre öğrencilerin teknolojiye yönelik tutumlarına bakılmış ve şehirdeki öğrencilerin teknolojiye yönelik tutumlarının daha olumlu olduğu belirlenmiştir. Cinsiyet değişkenine göre öğrencilerin tutumlarında fark olup olmadığına bakıldığında, erkek öğrencilerin teknolojiye yönelik tutumlarının kız öğrencilere göre daha olumlu olduğu bulunmuştur. Öğrencilerin sınıf düzeyine göre teknolojiye yönelik tutumları incelendiğinde 6 . ve 7 . sınıf öğrencileri ile 6 . ve 8 . sinıf öğrencileri arasında anlamlı fark olduğu ve bu farkın 7. ve 8. sınıf lehine olduğu belirlenmiştir.

Anahtar kelimeler: Teknoloji, tutum, ortaokul öğrencileri

\footnotetext{
* 7. Uluslararası Bilgisayar ve Öğretim Teknolojileri Sempozyum'unda sözlü bildiri olarak sunulmuştur (2013).

** Yrd. Doç. Dr., Kafkas Üniversitesi Eğitim Fakültesi, s.g.yalmanci@gmail.com

*** Yrd. Doç. Dr., Kafkas Üniversitesi Eğitim Fakültesi, solmazaydn@gmail.com
} 


\title{
The Examination of Middle School Students' Attitudes Towards Technology in Terms of Some Variables
}

\begin{abstract}
The aim of this study was examined the middle school students' attitudes towards technology, in terms of some variables. General survey method was used in this study. The sample of this study was composed of randomly selected a total of $4006^{\text {th }}, 7^{\text {th }}$ and $8^{\text {th }}$ grade middle school students, studying at three city center and three connected to the center of the village middle school in Kars. The Turkish version of the attitude towards technology (ÖTYT-TR) scale was used in this study. The independent samples $t$ test was used to determine the effect of gender and place of residence variables on students' attitudes towards technology. Data analysis was conducted to determine the effect of class-level variable using One-Way ANOVA post hoc Tukey HSD test. As a result, in term of place of residence variable, students' attitudes towards technology in the city center schools are more positive. According to gender variable was found that male students have more positive attitude towards technology than female students. Analyzed by grade level of students' attitudes towards technology was determined the significant difference between $6^{\text {th }}$ and $7^{\text {th }}$ grade with $6^{\text {th }}$ and $8^{\text {th }}$ grade. This difference was found in favor of the $7^{\text {th }}$ and $8^{\text {th }}$ grade.
\end{abstract}

Key Words: Technology, attitude, middle school students 


\section{Giriş}

Teknolojiyi üreten ve kullananlar bilgiye sahip toplumlardır. Bu durum toplumları ve bireyleri olaylar ve olgular karşısında daha güçlü yaparak hayatı kolaylaştırır. Teknolojiyi yaşamlarıyla bütünleştirenler diğer toplumlardan bir adım önde olmaktadırlar (Gündüz ve Odabaşı, 2004). Teknoloji, teknik bilgilerin hayata geçirilmesini sağlayan bütün toplumsal ve ekonomik etkinlikleri aynı zamanda örgütlenmeleri kapsayan bir alandır. Bilimsel ilke ve yeniliklerin, sorunların çözümüne uygulanmasını sağlarken, yaşamın kolaylaştırılmasına da katkı sağlar. Aynı zamanda bilginin artmasına da etki etmektedir (Middlehurst, 1999). Gelecek nesillerin artan bu bilgiyi iyi bir şekilde kullanmaları teknoloji destekli eğitim-öğretim etkinliklerinin katkısı ile gerçekleşebilir.

Eğitim öğretim etkinliklerinde öğrencilerin teknolojiden yararlanabilmesi ve teknoloji derslerinin bütün programlarda yer alması için altyapının sağlanması gerekmektedir. Böylece birey teknoloji okur-yazarı olacak ve toplumla olan ilişkilerinde bilinçlenecektir (Köse, Gencer ve Gezer, 2007). Teknoloji okuryazarlığı teknolojiyi anlama, yönetme ve değerlendirme yeteneğidir. Teknoloji okuryazarı bir birey teknolojinin ne olduğunu, nasıl ortaya çıkarıldığını, toplumu nasıl şekillendirdiğini ve toplum tarafından nasıl şekillendirildiğini anlayan insandır. Böyle kişiler teknolojiyle ilgili haberleri duyabilecek, değerlendirebilecek ve buna bağlı olarak bir fikir oluşturabilecektir. Ayrıca teknoloji hakkında rahat ve objektif olabilecektir (ITEA, 2000). Bu açıdan teknolojinin öğretim sürecine entegrasyonu önemlidir ve öğretmenlerin teknoloji okur-yazarlıklarını artırmaları gerekmektedir (Holloway, 2005). Elbette ki bunun için öğretmenlere destek olunmalı, gereken zaman ve imkânlar sağlanmalıdır. Böylece öğretmenler kendilerini geliştirebilirler (Bacanak, Karamustafaoğlu ve Köse, 2003). Bu konuda öğretmenlerin yeterli olması onların yetiştireceği öğrencilerinde teknoloji okuryazarlıklarını, tutumlarını ve güncel hayatlarında teknolojiden yararlanma derecelerini etkileyecektir.

Günümüz teknoloji çağında teknoloji eğitimden ayrı düşünülemez. Eğitimin her kademesinde bilgisayar destekli eğitim süreci uygulanmakta ve teknolojik unsurlar birçok açıdan kullanılmaktadır. Ayrıca yapılan çalışmalar eğitimde teknoloji kullanımının öğrencinin performansını ve başarısını artırdığını göstermektedir (Cradler, McNabb, Freeman ve Burchett, 2002). Dolayisiyla eğitim sürecinde bu kadar önemli olan teknolojiye yönelik olumlu tutum öğrenmeye yönelik olumlu bir tutumu da beraberinde getirecektir. Bu konuda ülkemizde yapılan çalışmalar incelendiğinde genellikle öğretmen adaylarının teknolojiye yönelik tutumları üzerine araştırmalar yapıldığı (Deniz, Görgen ve 
Şeker, 2006; Gerçek, Köseoğlu, Yılmaz ve Soran 2006; Yavuz ve Coşkun, 2008), öğrencilerin teknolojiye yönelik tutumları üzerine yapılan çalışmaların az sayıda olduğu görülmüştür (Mıhladız, Duran ve Yıldırım, 2011; Altun, 2011). $\mathrm{Bu}$ nedenle çalışmanın amacı ilköğretim öğrencilerinin teknolojiye yönelik tutumların belirlemek ve tutumların yerleşim yeri, cinsiyet ve sınıf düzeyine göre farklılaşıp farklılaşmadığını incelemek şeklinde belirlenmiştir. Bu çalışma ile ilköğretim öğrencilerinin olumlu ya da olumsuz tutumlarına sebep olan etkenlerin ve bu konuda neler yapılacağının tartışılmasına imkân sağlanacağı düşünülmektedir. Temel amaç doğrultusunda şu alt problemlere cevap aranmıştır.

1. Öğrencilerin yerleşim yerine göre teknolojiye yönelik tutum ölçeğinden aldıkları puanlar arasında bir farklılık var midır?

2. Öğrencilerin cinsiyete göre teknolojiye yönelik tutum ölçeğinden aldıkları puanlar arasında bir farklılık var midır?

3. Şehir ve köylerde öğrenim gören öğrencilerin cinsiyete göre teknolojiye yönelik tutum ölçeğinden aldıkları puanlar arasında bir farklılık var midır?

4. Öğrencilerin sınıf düzeyine göre teknolojiye yönelik tutum ölçeğinden aldıkları puanlar arasında bir farklılık var midır?

5. Şehir ve köylerde öğrenim gören öğrencilerin sınıf düzeyine göre teknolojiye yönelik tutum ölçeğinden aldıkları puanlar arasında bir farklılık var midır?

\section{Yöntem}

\section{Model}

Bu çalışmada, ilköğretim öğrencilerinin teknolojiye yönelik tutumlarını ölçmek amacıyla genel tarama modeli kullanılmıştır. Genel tarama modeli çok sayıda elemandan oluşan evrenden alınan bir grup, örnek ya da örneklem üzerinde yapılan tarama çalışmalarıdır (Karasar, 2012).

\section{Evren ve Örneklem}

Araştırmanın evrenini Kars ilinde bulunan ilköğretim okulları oluşturmaktadır. Araştırmanın örneklemi iki aşamalı olarak belirlenmiştir. İlk olarak toplam 22 ilköğretim okulundan üçü Kars il merkezinde üçü de merkeze bağlı köylerde bulunan okullardan random olarak seçilmiştir. İkinci aşamada ise bu okullarda öğrenim gören öğrencilerden random olarak 400 ortaokul öğrencisi belirlenerek çalışmaya alınmıştır. Örneklem grubunun değişkenlere göre dağılımı Tablo 1'de gösterilmiştir. 
Tablo 1. Öğrencilerin değişkenlere göre dağılımları

\begin{tabular}{llll}
\hline Değişken & & Frekans (f) & Yüzde (\%) \\
\hline \multirow{3}{*}{ Yerleşim Yeri } & Şehir & 200 & 50 \\
\cline { 2 - 4 } & Köy & 200 & 50 \\
\cline { 2 - 4 } & Toplam & 400 & 100 \\
\hline \multirow{3}{*}{ insiyet } & Kiz & 176 & 44 \\
\cline { 2 - 4 } & Erkek & 224 & 56 \\
\cline { 2 - 4 } & Toplam & 400 & 100 \\
\hline \multirow{3}{*}{ sınıf } & 6. sinif & 115 & 28.75 \\
\cline { 2 - 4 } & 7. sinif & 139 & 34.75 \\
\cline { 2 - 4 } & 8. sinif & 146 & 36.5 \\
\cline { 2 - 4 } & Toplam & 400 & 100 \\
\hline
\end{tabular}

\section{Veri Toplama Aracı}

Bu çalışmada 1988 yılında Vries tarafından“Öğrencilerin teknolojiye yönelik tutumları"(ÖTYT) adlı proje kapsamında geliştirilmiş ve 1989 yılında Barne ve Dugger tarafından İngilizceye uyarlanmış olan Teknolojiye Yönelik Tutum Ölçeğinin (ÖTYT-TR) Yurdugül ve Aşkar (2008) tarafından Türkçeye uyarlanmış versiyonu kullanılmıştır.

Teknolojiye Yönelik Tutum Ölçeği dünyada $25^{\prime}$ ten fazla ülkede uygulanmıştır. Altı boyuttan oluşan ölçeğin Türkçe formunda (ÖTYT-TR) 2 boyutun öğrencilerin teknolojiye yönelik genel tutum boyutunu yordamadığ1 gözlenmiştir. Bu sonuçlara göre ÖTYT-TR ölçeğinde öğrencilerin teknolojiye yönelik genel tutumlarının 4 alt boyuttan oluştuğu rapor edilmiştir. Ölçeğin son hali (ÖTYT-TR) 24 maddeden oluşmakta ve ölçeğin beşli likert tipinde dört alt boyutu bulunmaktadır. Bu boyutlar: Teknolojiye yönelik eğilim, teknolojinin önemi, teknolojinin olumsuzluğu, herkes için teknoloji şeklindedir. Ölçeğin güvenirliği için iç tutarlılığı McDonald'ın (1985) $\square \square$ (omega) katsayısı ile araştırılmış ve güvenirlik katsayısı 0,93 olarak elde edilmiştir.

\section{Veri Analizi}

Ölçeğin örneklem grubuna uygulanması sonucunda elde edilen verilerin SPSS programı ile analizleri yapılmıştır. Öğrencilerin ölçekten aldıkları puanlar toplanmış ve her bir öğrenci için bir tutum puanı elde edilmiştir. Araştırmanın alt problemleri doğrultusunda; öğrencilerin teknolojiye yönelik tutumlarında cinsiyet ve yerleşim yeri değişkenlerinin etkisini belirlemek için bağımsız gruplar $\mathrm{t}$ testi kullanılmıştır. Sınıf düzeyi değişkeninin etkisini belirlemek için 
de Tek Yönlü Varyans Analizi-Post Hoc Tukey HSD Testi kullanılarak veri analizi yapılmıştır.

\section{Bulgular}

Bu çalışmada öğrencilerin, ölçekten alabileceği en yüksek puan 120 en düşük puan ise 24 olarak belirlenmiştir. Öğrencilerin teknolojiye yönelik tutum ölçeğinden aldıkları puanlara göre betimsel istatistik değerleri aşağıdaki gibidir.

Tablo 2. Öğrencilerin teknolojiye yönelik tutum ölçeğinden aldikları puanlara göre betimsel istatistik değerleri

\begin{tabular}{lllcccc}
\hline $\mathrm{N}$ & Min. & Maks & Ort. & Standart Sapma & Med. & Mod \\
\hline 400 & 39 & 119 & 81.03 & 16.47 & 83 & 99 \\
\hline
\end{tabular}

Tablo 2'ye göre öğrencilerin tutum ölçeğinden aldıkları puanlar normal dağılım göstermektedir. Ayrıca ölçekten alınan puanlara göre elde edilen çarpıklık katsayısının (skewness $=-.183)$, standart hatasına $(s h=.122)$ bölünmesi ile elde edilen $\mathrm{z}$ istatistiğinin 1.96 'dan küçük çıktığı görülmüştür (skewness/sh=1.5). Bu durum dağılımın normalden aşırı bir sapma göstermediğini belirtir (Büyüköztürk, 2002). Öğrenciler tutum ölçeğinden minimum 39, maksimum 119 puan almışlardır. Bu durumda ortalamanın 81.03 olması öğrencilerin teknolojiye yönelik tutumlarının iyi düzeyde olduğunu göstermektedir.

\section{Birinci Alt Probleme Ait Bulgular}

Araştırmanın birinci alt problemi, Öğrencilerin yerleşim yerine göre teknolojiye yönelik tutum ölçeğinden aldıkları puanlar arasında bir farklılık var mıdır? şeklindedir. Bu alt problemi sınamak amacıyla bağımsız gruplar $t$ testi yapılmıştır. Elde edilen bulgular Tablo 3'te gösterilmektedir.

Tablo 3. Yerleşim yeri değişkenine göre öğrencilerin tutum ölçeğinden aldıklar puanlara ilişkin bağımsız gruplar t testi tablosu

\begin{tabular}{cccccc}
\hline $\begin{array}{c}\text { Yerleşim } \\
\text { yeri }\end{array}$ & $\mathrm{N}$ & Ortalama & $\mathrm{df}$ & $\mathrm{t}$ & $\mathrm{p}$ \\
\hline Şehir & 200 & 88.45 & 398 & 10.07 & .00 \\
Köy & 200 & 73.62 & 398 & & 1.00 \\
\hline
\end{tabular}

Tablo 3 incelendiğinde yerleşim yeri değişkeni açısından şehir ve köyde öğrenim gören öğrencilerin tutum ölçeğinden aldıkları puanlar arasında anlamlı bir fark bulunmuştur $(t(398)=10.07, p<.05)$. Ortalamalar incelendiğinde şehirde öğrenim gören öğrencilerin tutum ölçeğinden aldıkları puan ortalaması 
$\bar{X}=88.45$, köyde öğrenim gören öğrencilerin ortalaması $\bar{X}=73.62$ dir. Bu durum şehirde öğrenim gören öğrencilerin köyde öğrenim gören öğrencilere göre teknolojiye yönelik daha pozitif ve orta seviyede bir tutuma sahip olduklarını göstermektedir.

\section{İkinci Alt Probleme Ait Bulgular}

Araştırmanın ikinci alt problemi, Öğrencilerin cinsiyete göre teknolojiye yönelik tutum ölçeğinden aldıkları puanlar arasında bir farklılık var mıdır? şeklindedir. Bu alt problemi sınamak amacıyla yapılan bağımsız gruplar $t$ testi tablosu aşağıda verilmiştir.

Tablo 4. Cinsiyet değişkenine göre öğrencilerin tutum ölçeğinden aldıkları puanlara ilişkin bağımsız gruplar t testi tablosu

\begin{tabular}{cccccc}
\hline Cinsiyet & $\mathrm{N}$ & Ortalama & $\mathrm{df}$ & $\mathrm{t}$ & $\mathrm{p}$ \\
\hline K1z & 176 & 78.82 & \multirow{2}{*}{398} & -2.38 & .01 \\
Erkek & 224 & 82.77 & & & \\
\hline
\end{tabular}

Tablo 4'e bakıldığında kız öğrencilerin tutum ölçeğinden aldıkları puan ortalaması $\quad \bar{X}=78.82$, erkek öğrencilerin ortalaması da $\bar{X}=82.77$ olarak bulunmuştur. Yapılan bağımsız gruplar $\mathrm{t}$ testi sonucuna göre cinsiyet değişkeni açısından kız ve erkek öğrencilerin tutum ölçeğinden aldıkları puanlar arasında anlamlı bir fark bulunmuştur $(t(398)=-2.38, \quad p<.05)$. Bu durumda erkek öğrencilerin kız öğrencilere göre teknolojiye yönelik tutumlarının daha pozitif ve orta seviyede olduğu söylenebilir.

\section{Üçüncü Alt Probleme Ait Bulgular}

Araştırmanın üçüncü alt problemi, Şehir ve köylerde öğrenim gören öğrencilerin cinsiyete göre teknolojiye yönelik tutum ölçeğinden aldıklar puanlar arasinda bir farklılık var mıdır? şeklindedir. Bu alt problemi sinamak amacıyla yapılan bağımsız gruplar $\mathrm{t}$ testi tablosu aşağıda verilmiştir.

Tablo 5. Cinsiyet değişkenine göre şehir ve köylerde öğrenim gören öğrencilerin tutum ölçeğinden aldıkları puanlara ilişkin bağımsız gruplar t testi tablosu

\begin{tabular}{|c|c|c|c|c|c|c|}
\hline Yerleşim yeri & Cinsiyet & $\mathrm{N}$ & Ortalama & $\mathrm{df}$ & $t$ & $\mathrm{p}$ \\
\hline \multirow[t]{2}{*}{ Şehir } & Kız & 90 & 85.33 & \multirow{2}{*}{198} & \multirow{2}{*}{-3.28} & \multirow{2}{*}{.00} \\
\hline & Erkek & 110 & 91 & & & \\
\hline \multirow[t]{2}{*}{ Köy } & K1z & 86 & 72.02 & \multirow{2}{*}{198} & \multirow{2}{*}{-1.17} & \multirow{2}{*}{.24} \\
\hline & Erkek & 114 & 74.82 & & & \\
\hline
\end{tabular}


Tablo 5'e bakıldığında şehirde öğrenim gören kız öğrencilerin tutum ölçeğinden aldıkları puan ortalaması $\bar{X}=85.33$, erkek öğrencilerin ortalaması da $\bar{X}=91$ olarak bulunmuştur. Yapılan bağımsız gruplar $\mathrm{t}$ testi sonucuna göre cinsiyet değişkeni açısından şehirde öğrenim gören kız ve erkek öğrencilerin tutum ölçeğinden aldıkları puanlar arasında anlamlı bir fark bulunmuştur $(t(198)=-3.28, p<.05)$. Bu durumda şehirde öğrenim gören erkek öğrencilerin kız öğrencilere göre teknolojiye yönelik tutumlarının daha pozitif ve orta seviyede olduğu söylenebilir.

Tablo 5 dikkate alındığı zaman köyde öğrenim gören kız öğrencilerin tutum ölçeğinden aldıkları puan ortalaması $\bar{X}=72.02$, erkek öğrencilerin ortalaması da $\bar{X}=74.82$ olarak bulunmuştur. Yapılan bağımsız gruplar $\mathrm{t}$ testi sonucuna göre cinsiyet değişkeni açısından şehirde öğrenim gören kız ve erkek öğrencilerin tutum ölçeğinden aldıkları puanlar arasında anlamlı bir fark olmadığı görülmüştür $(t(198)=-1.17, p>.05)$. Bu durumda köyde öğrenim gören kız ve erkek öğrencilerin teknolojiye yönelik tutumlarının birbirine yakın, pozitif ve orta seviyede olduğu söylenebilir.

\section{Dördüncü Alt Probleme Ait Bulgular}

Araştırmanın dördüncü alt problemi, Öğrencilerin sinı düzeyine göre teknolojiye yönelik tutum ölçeğinden aldıklar puanlar arasında bir farklılık var mıdır? şeklindedir. Öğrencilerin sınıf düzeyine göre teknolojiye yönelik tutum ölçeğinden aldıkları puanların betimsel istatistik değerleri aşağıdaki gibidir.

Tablo 6. Öğrencilerin sinıf düzeyine göre teknolojiye yönelik tutum ölçeğinden aldikları puanlarm betimsel istatistik değerleri

\begin{tabular}{cccc}
\hline Sınıf Düzeyi & $\mathrm{N}$ & Ortalama & Standart Sapma \\
\hline 6. Düzey & 115 & 71.81 & 17.97 \\
\hline 7. Düzey & 139 & 82.14 & 16.23 \\
\hline 8. Düzey & 146 & 87.24 & 11.62 \\
\hline
\end{tabular}

Tablo 6'ya göre altıncı sınıf öğrencilerinin teknolojiye yönelik tutum ölçeğinden aldıkları puanların ortalaması $\bar{X}=71.81^{\prime}$ dir. Yedinci sını öğrencilerinin puan ortalaması $\quad \bar{X}=82.14$ ve 8 . sınıf öğrencilerinin ortalamasının ise $\bar{X}=87.24$ olduğu görülmektedir.

Öğrencilerin sınıf düzeyine göre teknolojiye yönelik tutum ölçeğinden aldıkları puanlar arasında anlamlı bir farklılık olup olmadığını belirlemek için tek yönlü ANOVA testine ilişkin tablo aşağıda verilmiştir. 
Ortaokul Öğrencilerinin Teknolojiye Yönelik Tutumlarının Bazı Değişkenler Açısından İncelenmesi

133

Tablo 7. Öğrencilerin sınıf düzeyine göre teknolojiye yönelik tutum ölçeğinden aldıkları puanlara yönelik ANOVA testi

\begin{tabular}{|c|c|c|c|c|c|c|}
\hline $\begin{array}{l}\text { Varyans } \\
\text { Kaynağ1 }\end{array}$ & $\begin{array}{l}\text { Kareler } \\
\text { Toplamı }\end{array}$ & $\mathrm{df}$ & $\begin{array}{l}\text { Kareler } \\
\text { Ortalamas1 }\end{array}$ & $\mathrm{F}$ & $\mathrm{P}$ & $\begin{array}{l}\text { Sinif Düzeyindeki } \\
\text { Fark (Tukey testi) }\end{array}$ \\
\hline $\begin{array}{l}\text { Gruplar } \\
\text { aras1 }\end{array}$ & 15575,027 & 2 & 7787.51 & \multirow[t]{3}{*}{33.32} & \multirow[t]{3}{*}{.00} & \multirow[t]{3}{*}{$6-7,6-8$} \\
\hline $\begin{array}{l}\text { Gruplar } \\
\text { İçi }\end{array}$ & 92781,411 & 397 & 233.70 & & & \\
\hline Toplam & 108356,438 & 399 & & & & \\
\hline
\end{tabular}

Tablo 7'de görüldüğü gibi ANOVA testi sonucuna bakıldığında, öğrencilerin sınıf düzeyine göre teknolojiye yönelik tutum ölçeğinden aldıkları puanlar arasında anlamlı bir fark bulunmuştur $(F(2.397)=33.32, p<.05)$. Bu farkın hangi sınıf düzeyinde olduğunu belirlemek için yapılan Tukey testine göre altıncı ve yedinci sınıf öğrencileri ile altıncı ve sekizinci sınıf öğrencileri arasında anlamlı fark olduğu belirlenmiştir. Tablo 5 'teki ortalamalara bakıldığında yedinci ( $\bar{X}=82.14)$ ve sekizinci $(\bar{X}=87.24)$ siniflara göre altıncı $(\bar{X}=71.81)$ sinifta öğrenim gören öğrencilerin teknolojiye yönelik tutum ölçeğinden aldıkları puan ortalaması daha düşüktür. Dolayısı ile bu farkın yedinci ve sekizinci sınıf lehine olduğu söylenebilir.

\section{Beşinci Alt Probleme Ait Bulgular}

Araştırmanın beşinci alt problemi, Şehir ve köylerde öğrenim gören öğrencilerin sinıf düzeyine göre teknolojiye yönelik tutum ölçeğinden aldıkları puanlar arasında bir farklılık var mıdır? şeklindedir. Şehir ve köylerde öğrenim gören öğrencilerin sınıf düzeyine göre teknolojiye yönelik tutum ölçeğinden aldıkları puanların betimsel istatistik değerleri aşağıdaki gibidir.

Tablo 8. Şehir ve köylerde öğrenim gören öğrencilerin sinıf düzeyine göre teknolojiye yönelik tutum ölçeğinden aldıkları puanların betimsel istatistik değerleri

\begin{tabular}{lllll}
\hline Yerleşim Yeri & Sinıf Düzeyi & $N$ & Ortalama & $\begin{array}{l}\text { Standart } \\
\text { Sapma }\end{array}$ \\
\hline \multirow{3}{*}{ Şehir } & 6. Düzey & 45 & 90.20 & 11.09 \\
\cline { 2 - 5 } & 7. Düzey & 77 & 88.33 & 13.57 \\
\cline { 2 - 5 } & 8. Düzey & 78 & 87.56 & 12.04 \\
\hline \multirow{3}{*}{ Köy } & 6. Düzey & 70 & 60 & 9.65 \\
\cline { 2 - 5 } & 7. Düzey & 62 & 74.45 & 16.06 \\
\cline { 2 - 5 } & 8. Düzey & 68 & 86.88 & 11.20 \\
\hline
\end{tabular}


Tablo 8'e göre şehirde öğrenim gören altıncı sınıf öğrencilerinin teknolojiye yönelik tutum ölçeğinden aldıkları puanların ortalaması $\bar{X}=90.20^{\prime}$ dir. Yedinci sınıf öğrencilerinin puan ortalaması $\bar{X}=88.33$ ve sekizinci sınıf öğrencilerinin ortalamasının ise $\bar{X}=87.56$ olduğu görülmektedir. Köyde öğrenim gören öğrencilerinin teknolojiye yönelik tutum ölçeğinden aldıkları puanların ortalamalarına bakıldığında ise altıncı sınıf öğrencilerinin puan ortalaması $\bar{X}=60$, yedinci sınıf öğrencilerinin puan ortalaması $\bar{X}=74.45$ ve sekizinci sınıf öğrencilerinin ortalamasının ise $\bar{X}=86.88$ olduğu görülmektedir.

Şehir ve köylerde öğrenim gören öğrencilerin sınıf düzeyine göre teknolojiye yönelik tutum ölçeğinden aldıkları puanlar arasında anlamlı bir farklılık olup olmadı̆̆ını belirlemek için tek yönlü ANOVA testine ilişkin tablo aşağıda verilmiştir.

Tablo 9. Şehir ve köylerde öğrenim gören öğrencilerin sinı düzeyine göre teknolojiye yönelik tutum ölçeğinden aldıkları puanlara yönelik ANOVA test $i$

\begin{tabular}{|c|c|c|c|c|c|c|c|}
\hline $\begin{array}{l}\text { Yerleşim } \\
\text { Yeri }\end{array}$ & $\begin{array}{l}\text { Varyans } \\
\text { Kaynağ1 }\end{array}$ & $\begin{array}{l}\text { Kareler } \\
\text { Toplamı }\end{array}$ & $\mathrm{df}$ & $\begin{array}{l}\text { Kareler } \\
\text { Ortalaması }\end{array}$ & $\mathrm{F}$ & $\mathrm{p}$ & $\begin{array}{l}\text { Sinif } \\
\text { Düzeyindeki } \\
\text { Fark (Tukey } \\
\text { testi) }\end{array}$ \\
\hline \multirow[t]{3}{*}{ Şehir } & $\begin{array}{l}\text { Gruplar } \\
\text { arası }\end{array}$ & 199.99 & 2 & 99.99 & \multirow{3}{*}{.64} & \multirow{3}{*}{.52} & \\
\hline & $\begin{array}{l}\text { Gruplar } \\
\text { içi }\end{array}$ & 30577.60 & 197 & 155.21 & & & \\
\hline & Toplam & 30777.59 & 199 & & & & \\
\hline \multirow[t]{3}{*}{ Köy } & $\begin{array}{l}\text { Gruplar } \\
\text { aras1 }\end{array}$ & 24988.70 & 2 & 12494.35 & \multirow{3}{*}{.80} & \multirow{3}{*}{.00} & \multirow{3}{*}{$6-7,6-8,7-8$} \\
\hline & $\begin{array}{l}\text { Gruplar } \\
\text { içi }\end{array}$ & 30582.41 & 197 & 155.24 & & & \\
\hline & Toplam & 55571.12 & 199 & & & & \\
\hline
\end{tabular}

Tablo 9'da görüldüğü gibi ANOVA testi sonucuna bakıldığında, şehirde öğrenim gören öğrencilerin sınıf düzeyine göre teknolojiye yönelik tutum ölçeğinden aldıkları puanlar arasında anlamlı bir fark görülmemiştir $(F(2.197)=$ $64, p>$.05). Bu durumda şehirde öğrenim gören öğrencilerin teknolojiye yönelik tutumlarının sınıf düzeyi açısından yakın seviyede olduğu söylenebilir. Tablo 9'a bakıldığında köyde öğrenim gören öğrencilerin sınıf düzeyine göre teknolojiye yönelik tutum ölçeğinden aldıkları puanlar arasında anlamlı bir fark görülmüştür $(F(2.197)=80, p<.05)$. Bu farkın hangi sınıf düzeyinde olduğunu belirlemek için yapılan Tukey testine göre her sınıf düzeyinde anlamlı bir fark 
belirlenmiştir. Tablo 7 'deki ortalamalara bakıldığında sekizinci sınıf düzeyindeki öğrencilerin teknolojiye yönelik tutum ölçeğinden aldıkları puan ortalamasının diğer altıncı ve yedinci sınıf düzeyindeki öğrencilere göre daha yüksek olduğu görülür. Dolayısı ile bu farkın sekizinci sınıf lehine olduğu söylenebilir.

\section{Sonuç ve Tartışma}

İköğretim öğrencilerinin teknolojiye yönelik tutumlarını bazı değişkenler açısından incelemek amaciyla yapılan bu çalışmada yerleşim yerine göre öğrencilerin tutumlarına bakılmış ve sonuçta şehirdeki öğrencilerin teknolojiye yönelik tutumlarının daha olumlu olduğu belirlenmiştir. İl merkezlerinde öğrenim gören öğrencilerin çeşitli teknolojik aletleri bulundurma, bu aletlere ulaşma imkânının fazla olması ve teknolojik araçları kullanabilmeleri; köylerde eğitim gören öğrencilere göre teknolojiye yönelik tutumlarının olumlu yönde gelişmesini sağlamış olabilir. Benzer şekilde Altun (2011) öğrencilerin bilgisayara yönelik tutumlarını incelediği araştırmasında ilköğretim öğrencilerinin yerleşim yeri bakımından bilgisayara yönelik tutumlarında il ve ilçe merkezlerindeki öğrencilerin köydeki öğrencilere oranla daha olumlu bir tutuma sahip olduklarını tespit etmiştir.

Cinsiyet değişkenine göre öğrencilerin tutumlarında fark olup olmadığına bakıldığında, genel olarak erkek öğrencilerin teknolojiye yönelik tutumlarının kız öğrencilere göre daha olumlu olduğu belirlenmiştir. Bu durum şehirdeki okullarda öğrenim gören erkek öğrenciler için de geçerlidir. Ancak köy okullarında öğrenim gören öğrencilere bakıldığında öğrencilerin teknolojiye yönelik tutumlarında cinsiyetleri açısından bir fark görülmemiştir. Whitley (1997), de çalışmasında erkek öğrencilerin bilgisayara yönelik tutumunun kız öğrencilere göre daha olumlu olduğunu belirlemiştir. Bakr (2011), Köse ve Gezer (2006), Bush (1995) ise cinsiyet değişkenine dair anlamlı bir fark bulamamışlardır. Bu çalışmaların dışında Galpin ve Sander (2007) bilgisayar kursu öncesi ve sonrası öğrencilerin cinsiyetlerine göre algılarının nasıl değiştiğini inceledikleri çalışmalarında bazı maddeler açısından farklılık görmüş̧lerdir. Erdemir, Bakırcı ve Eyduran (2009) cinsiyet değişkenini teknolojiyi öğretimde kullanabilme özgüveni açısından değerlendirmişler ve bazı maddeler açısından fark bulunurken, bazı maddeler açısından da cinsiyet arasında fark bulunmamışır. Bazı çalışmalarda da tutum ölçeğinde kızlar lehine fark bulunmuştur (Loyd, Loyd ve Gressard, 1987; Ray, Sormunen ve Harris, 1999).

Öğrencilerin sınıf düzeyine göre teknolojiye yönelik tutumları incelendiğinde altıncı ve yedinci sınıf öğrencileri ile altıncı ve sekizinci sınıf öğrencileri 
arasında anlamlı fark olduğu ve bu farkın yedinci ve sekizinci sınıf lehine olduğu belirlenmiştir. Şehirde öğrenim gören öğrencilerin tutumlarına bakıldığında sınıf düzeyi açısından anlamlı fark görülmezken köyde öğrenim gören öğrencilerin tutumlarında tüm sınıf düzeyleri açısından anlamlı fark bulunmuştur. Bu fark sekizinci sınıf lehinedir. Bu durumda sınıf düzeyi yükseldikçe öğrencilerin de teknolojiye yönelik tutumlarında olumlu yönde bir farklılaşma olduğu söylenebilir. Mihladız, Duran ve Yıldırım (2011) çalışmalarında buna benzer bir sonuç elde etmişlerdir.

Çalışmadan elde edilen sonuçlar doğrultusunda eğitimde fırsat eşitliği sağlanmalı, şehirlerdeki okullarda olduğu kadar köy okullarının da teknolojik araç gereç bakımından donanımlı olmasına, orda bulunan halkın ve öğretmenlerin teknolojik araçları kullanmayı öğrenmesine, öğrencilerin teknolojik araçlara ulaşabilme imkânına kavuşmasına fırsat verilmelidir. Bu anlamda yapılan çalışmalar en kısa sürede tamamlanmalıdır. Günümüz artık teknoloji çağıdır, bu amaçla kız erkek ayırımı yapmadan ve insanların yaşı ne olursa olsun, öğrenim gördüğü sınıf düzeyi farkına bakılmaksızın herkesin teknolojiye yönelik olumlu bir tutum oluşturması sağlanmalıdır. Bunun için de teknoloji eğitim öğretimin ayrılmaz bir parçası olarak tüm öğretim programlarında bulundurulmalı, eğitime ayrılan katkı payları her sınıfın teknolojik araç gereçlerle donatılması için kullanılmalı, bu araç gereçlerin kullanımı öğretilmeli ve herkes teknolojik araç gereç kullanımı açısından desteklenmelidir. 


\section{Kaynakça}

Altun, T. (2011). İlköğretim öğrencilerinin bilgisayara yönelik tutumlarının incelenmesi: Trabzon ili örneği. Turkish Journal of Computer and Mathematics Education, 2(1), 69-86.

Bacanak, A., Karamustafaoğlu, O. ve Köse, S. (2003). Yeni bir bakış: Eğitimde teknoloji okuryazarlığı. PAÜ Eğitim Fakültesi Dergisi, 14(2), 191-196.

Bakr, S. M. (2011). Attitudes of Egyptian teachers towards computers. Contemporary Educational Technology, 2(4), 308-318.

Bush, T. (1995). Gender differences in self efficacy and attitudes toward computers. Journal of Educational Computing Research,12,147-158.

Büyüköztürk, Ş. (2002).Sosyal Bilimler İçin Veri Analizi El Kitabı. Ankara: Pegem Akademi

Cradler, J., McNabb, M., Freeman, M. ve Burchett, R. (2002). How does technology influence student learning? Learning and Leading with Technology, 29(8), 46-56.

Deniz, S., Görgen, İ. ve Şeker, H. (2006). Tezsiz yüksek lisans öğretmen adaylarının teknolojiye yönelik tutumları. Eurasian Journal of Educational Research, 23, 62-71.

Erdemir, N., Bakırcı, H. ve Eyduran E. (2009). Öğretmen adaylarının eğitimde teknolojiyi kullanabilme özgüvenlerinin tespiti. Türk Fen Eğitimi Dergisi, 6(3), 99-108.

Galpin, V. C. ve Sander, I. D. (2007). Perceptions of computer science at a South African University. Computers \& Education, 49, 1330-1356.

Gerçek, C., Köseoğlu, P., Yılmaz, M. ve Soran, H. (2006). Öğretmen adaylarının bilgisayar kullanımına yönelik tutumlarının çeşitli değişkenler açısından incelenmesi. Hacettepe Üniversitesi Ĕ̆itim Fakültesi Dergisi, 30, 130-139.

Gündüz Ş. ve Odabaşı F. (2004). Bilgi çağında öğretmen adaylarının eğitiminde öğretim teknolojileri ve materyal geliştirme dersinin önemi. The Turkish Online Journal of Educational Technology, 3(1), 43-48.

Holloway, S. D. (2005). Increasing technology integration throuh collaboration between media specialists and teachers.

http://teach.valdosta.edu/are/vol4no1/pdf/HollowaySArticle_0426.pd f adresinden 23.06.2013 tarihinde elde edildi.

International Technology Education Association (ITEA), (2007). Standards For Technological Literacy: Content for The Study of Technology, Reston, Virginia: International Technology Education Association. Retrieved from: http://www.iteea.org/TAA/PDFs/xstnd.pdf adresinden 25.06.2013 tarihinde elde edildi.

Karasar, N. (2012). Bilimsel araştırma yöntemi. Ankara: Nobel Yayıncılık. 
Köse, S. ve Gezer, K. (2006). Buldan (Denizli) ilçesi lise öğrencilerinin bilgisayara yönelik tutumları. Buldan Sempozyumu, Denizli.

Köse, S., Gencer A. S. ve Gezer K. (2007). Meslek yüksekokulu öğrencilerinin bilgisayar ve internet kullanımına yönelik tutumları. Pamukkale Üniversitesi Eğitim Fakültesi Dergisi, 1, 44-54.

Loyd, B. H., Loyd, D. E. ve Gressard, C. P. (1987). Gender and computer experience as factors in the computer attitudes of middle school students. Journal of Early Adolescence, 7(1), 13-19.

Mihladız, G., Duran, M. ve Yıldırım, M.Z. (2011). Investıgatıon of primary school students' attitudes towards technology.

http://lsg.ucy.ac.cy/esera/e_book/base/ebook/strand7/ebookesera2011_MIHLADIZ-07.pdf adresinden 31.12.2012 tarihinde elde edildi .

Middlehurst, R. (1999). New realities for leadership and governance in higher education? Tertiary Education and Management, 5, 307-329.

Ray, M. C., Sormunen, C. ve Harris, T. M. (1999). Men's and women's attitudes toward computer technology: A comparison. Information Technology, Learning, and Performance Journal, 17, 1-8.

Whitley, B. (1997). Gender differences in computer related attitudes and behavior: A meta-analysis. Computers in Human Behavior, 13(1), 1-22.

Yavuz, S. ve Coşkun, A.E. (2008). Sınıf öğretmenliği öğrencilerinin eğitimde teknoloji kullanımına ilişkin tutum ve düşünceleri. Hacettepe Üniversitesi Eğitim Fakültesi Dergisi, 34, 276-286.

Yurdugül H. ve Aşkar P. (2008). Investigation of the factorial structures of pupils' attitude towards technology (PATT): Turkish sample. Elementary Education Online, 7(2), 288-309. 